\title{
MODERNIZATION OF PUBLIC SPACE FLOOR AND ITS IMPACT ON AREA - THE EXAMPLE OF THE KOŚCIUSZKO SQUARE IN BIAŁYSTOK
}

\author{
Anna TOFILUK ${ }^{1}$ \\ Warsaw University of Technology, \\ Faculty of Civil Engineering,Warszawa, Poland
}

\begin{abstract}
The last 25 years have been in many Polish cities a period of intensive modernization and renewals of the existing public spaces. Most of all the resurfacing of the pavement and changing of street furniture have been held. In many cases, the transformations in the urban areas were integrated with exclusion from traffic. The question arises what criteria architects or landscape architects follow and what design solutions apply. It is also interesting how the new shape of the floor in public spaces (understood here as a pavement and street furniture together) can help to create integrating and activating space for residents. And how it can affect the quality of life in a wider area. This article attempts to answer these questions based on new solutions on Kosciuszko Square in Białystok, executed in 2005-2009.
\end{abstract}

Keywords: public space, street furniture, pavement, urban floor.

\section{INTRODUCTION}

The last 25 years have been in many Polish cities a period of intense modernization of public spaces, which largely boiled down to resurfacing and small architectural objects. Changes included firstly main squares and streets where one restricted or liquidated circular motion.

\footnotetext{
${ }^{1}$ Corresponding author: Warsaw University of Technology, Faculty of Civil Engineering, Institute of Building Engineering, al. Armii Ludowej 16, 00-637 Warszawa, Poland, e-mail: atofiluk@il.pw.edu.pl, tel. +48222345747
} 
For purposes including this article and doctoral dissertation [5] one formulated abbreviation PPPM (podłoga przestrzeni publicznej miasta) meaning floor of the city public space. It is understood as a walking surface combined with objects of small architecture. The extension of Wejchert's [9, p. 109] definition of the urban floor is justified by the fact that the surface together with the accompanying elements is a functional unit, and typically one design task. These upgrades were changes of PPPM. The question arises to what extent they affect the functioning of public spaces and how the new PPPM can contribute to creating values of the cultural area - understood as it was defined by A. Wallis [8, p.10] - and influence the quality of life in the city and what design procedures are taken for this purpose.

The article attempts to answer it on the basis of a new floor of Kosciuszko Square in Białystok. Its analysis was carried out in relation to previously defined urban floors functions [7].

\section{KOŚCIUSZKO SQUARE - LOCATION AND HISTORY}

Kosciuszko Square historically has been a major public space of Białystok. Destruction, planning changes and motorisation expansion after World War meant that the beginning of the twenty-first century was dominated by cars. Square was not a place that would allow the existence, in this area, of many other but communication activities.

Most likely the origins of the Square are the first half of the fifteenth century. Then, at the intersection of roads leading to Suraż, Wasilkowo and Choroszcz developed a triangular square, where in the mid-sixteenth century a church was erected. The one existing today was built in the early seventeenth century.

Around 1570 one built mansion adjacent to the Square, rebuilt by Branicki family in the seventeenth and eighteenth century in the palace garden. At the time of the rule of Jan Klemens Branicki (1689-1771) falls the best period in the history of the city. His decisions helped to shape the Square. "In 1708, by Hetman's initiative, a committee was set up for the reconstruction of the city centre. (...) ultimately the shape of the Square was defined. Extended frontage: north and south, a slight bend at the centre of the Square marked the functional division of space into the eastern part - related to the residence and the western part - serving urban functions. " [4, p. 103].

In the middle of the eighteenth century Białystok renewed the charter, it began construction of the city hall, then one built a hospital and the armoury building. From 1723 years the western part of the Square was the site of the market. Also, buildings next to the town hall and the scales building erected in $1772 \mathrm{had}$ trade functions. In the nineteenth century they formed a common market hall. 
In 1862 at the Square on its axis at the exit of the current Sienkiewicz street was established fountain. In the years 1900-1905 was built metropolitan cathedral there.

In 1918 next to the fountain was created Square Plaque of the Unknown Soldier. In 1940, the Russians pulled down the town hall and the scales building. In 1944 midtown buildings were destroyed. City Hall and the buildings around the Square were restored after the war. The ones in frontages have gained a greater height as compared to the former one-storey building. The basis for construction activities was the study by J. Glinka [2]. Despite the reconstruction, the square has changed the character - Sienkiewicz street was extended driving the southern frontage. It crossed the Square disrupting its connection to the palace. The fountain was moved to the green square built on the site of the former market and scales building.

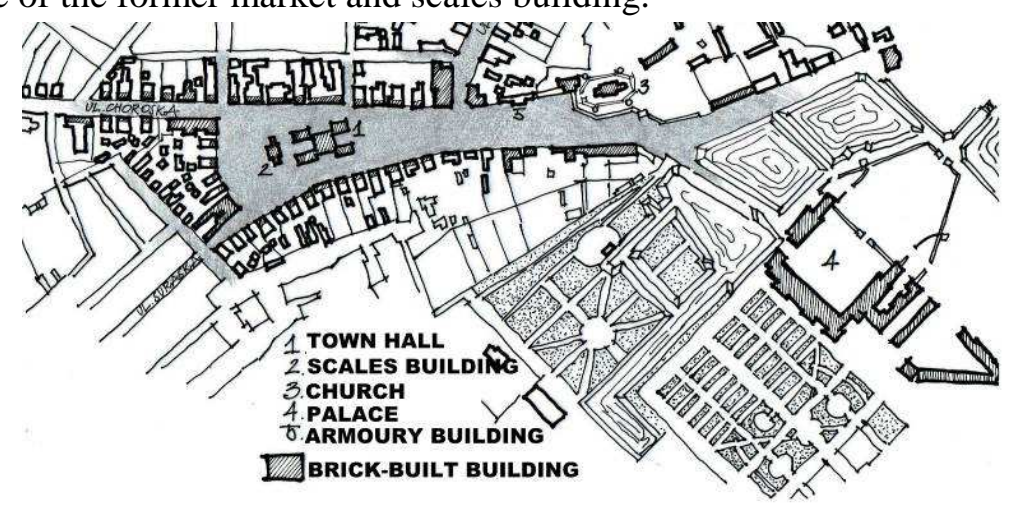

Fig. 1. Kosciuszko Square in the eighteenth century. Study: The author based on J.Glinka [2]

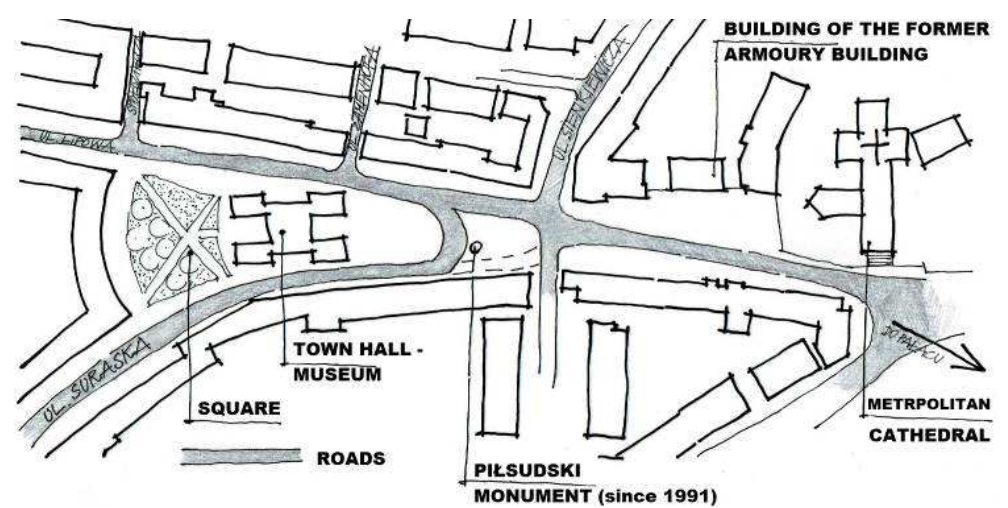

Fig. 2. Schematic Kosciuszko Square before the upgrade. Study: The author 
The extension of Sienkiewicz street and the growing number of vehicles made the Square turned into a space dominated by a road communication.

In 1991 a monument of Józef Piłsudski was built, in 2002 one restored the fountain, close to its original location.

\section{MODERNIZATION}

In 2005, a competition on the concept of modernization of the square plaque was completed and in 2006 one launched a 3-year-staged realization of the project by Zenon Zabagło. One replaced the surface, which are now made of granite slabs and paving stones, and introduced a number of elements of small architecture.

A decision that changed the functioning of the Square was to reduce the road communication. It remained on Sienkiewicz street, on both sides one created pedestrian areas. The Square intersection by road splits it up into two parts, but with the introduction of new pavement of uniform colour and the same figure on both sides, the areas make a clear sense.

An important change was also the modification of the Square topography. Before renovation plane of the floor on the western and southern side of the city hall rose towards the western facade and the opening of Suraska street. It was decided that a green square at the city hall will be replaced by the granite pavement, and the difference between it and the Suraska street and sidewalk along the western facade will be done by the terrain stairs split by terraces. Only the extension of the Suraska street retained the existing topography.

The new floor of the Square was subordinated to the six-mentioned features of PPPM and therefore will be further discussed.

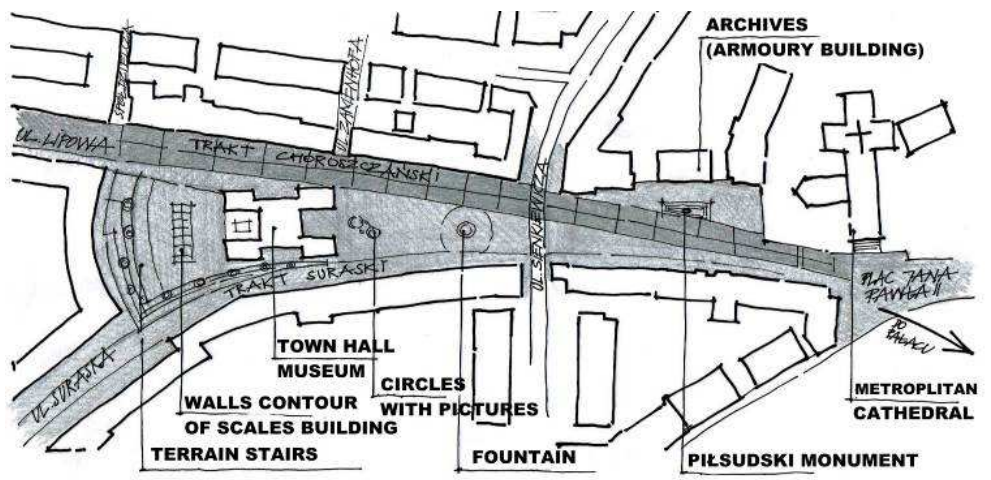

Fig. 3. Schematic Kosciuszko Square after modernization. Study: The author 


\subsection{Communications function}

An elongated shape and location to enter the Square make the main walking paths coincide with the course of previously existing roadway here. On the western side of the Square run floors, along the southern and northern frontage, on the western side roughly in the middle of triangle tapering in this direction and on both sides of the running Sienkiewicz street. Both routes running along the longer frontage of the Square are clear in the drawing of the floor, especially accentuated - with different colours and pattern pavement - is an extension of Lipowa street, which can also be seen when crossing the road at Sienkiewicz street and further continues on the eastern side of the Square. This ribbon of a different colour and pattern runs through the entire Square connecting the two parts and is intended to bring to mind the old Choroszcz route, who led from the Branicki Palace to Choroszcz.

Small architecture elements are set at the Square in such a way, so that it does not interfere with pedestrian traffic. Lanterns are set along the main roads, and also on some fragments-pots with greenery and two-sided benches.

The contradiction in the composition of the surface pattern is a partial occupation of Choroszcz route, marked in the floor, by summer gardens set along the northern frontage. Going from the cathedral towards Lipowa street, three dark lines in the surface, defining a road, lead passer-by the eastern part of the Square, "leading" him across the road, after which two of them are lost by furnishing of summer gardens. Route is sufficiently wide and its half delivers throughput of pedestrian flow, nevertheless, such a solution seems to be devoid of consequences.

One major obstacle for pedestrians is to cross Sienkiewicz street. This is possible in two locations equipped with traffic lights.

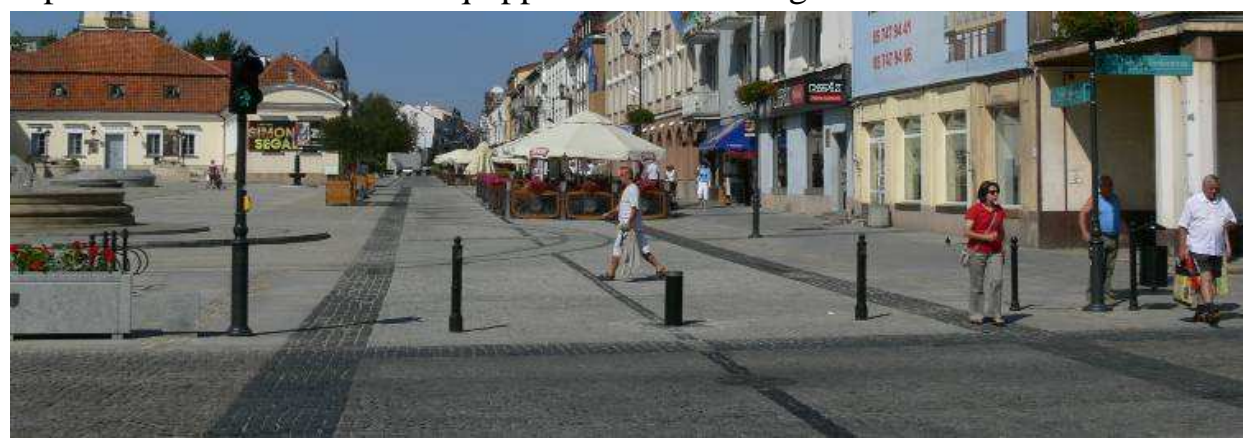

Fig. 4. Marking of Choroszcz route running. Photo by the author

Excluding the inconvenience of the road and the lack of consistency in stressing the route, solution of the new floor treats convenient pedestrian traffic as a matter of priority, the location of other functions are assigned to it. 


\subsection{Trade and service function}

The new floor in the summer is partly occupied by summer gardens of eating places. They are grouped on the western side of Sienkiewicz street along the northern and western frontage. Their furniture is moved away from structures, it is possible to walk freely, directly at elevations. Moreover, gardens are located at the town hall from the western side and the eastern side of Square, next to Sienkiewicz street. Here, the tables are set directly on the facades of buildings, but do not interfere with pedestrian traffic.

As mentioned, summer gardens on the extension of Lipowa street occupy half the Choroszcz route, marked in the surface and it is not a happy solution. At the same time one must note that the dividing lines in the surface drawing are the boundaries of their furniture, which arranges the area.

Second place in which several eating places "come out" from their headquarters and engage urban floor is terraces of terrain stairs on the western frontage. This location is a collision-free, from the point of view of the main walking routes, and also very attractive. Summer gardens have a structured, consistent and aesthetic form.

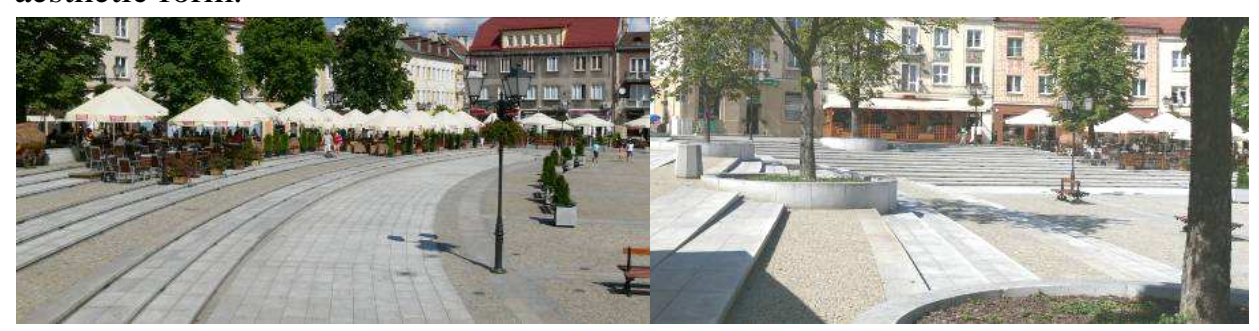

Fig. 5 Terraces of terrain stairs with summer gardens and trees. Photo by the author

Occasionally during various events and fairs floor of the Square in the large area temporarily receives commercial function. Stands are set primarily in the former market and scales building, thanks to the floor extent of the Square, this type of event can take place here without disturbing normal, everyday pace of the Square functioning.

It could also take place on other days of the year, if one organized daily trade at that location. This would be a continuation of the use tradition of the place discontinued at the end of the war. At the same time it could revive Square and make it serve citizens better not only in specific situations.

\subsection{Historical function}

The new configuration of the Kosciuszko Square can be regarded as an attempt to recreate how the Square looked to the Second World War. Clearing trees in the Square, fountains shift so that it was closer to the original location, the 
marking of historical communication routes aimed at relating to history. Also limiting vehicular traffic is a decision consistent with the historical, dominated by the pedestrian character of the place.

Specific solutions referring to the history, among other things, is previously mentioned fountain. Its form is a copy of the former one and is located approximately in the nineteenth-century location.

On the western side of the town hall one copied, in the floor, a drawing of scales building foundations. The elements directly informing how looked the Square are the stone circles at the entrance to the town hall, there were placed archival photographs of the Square.

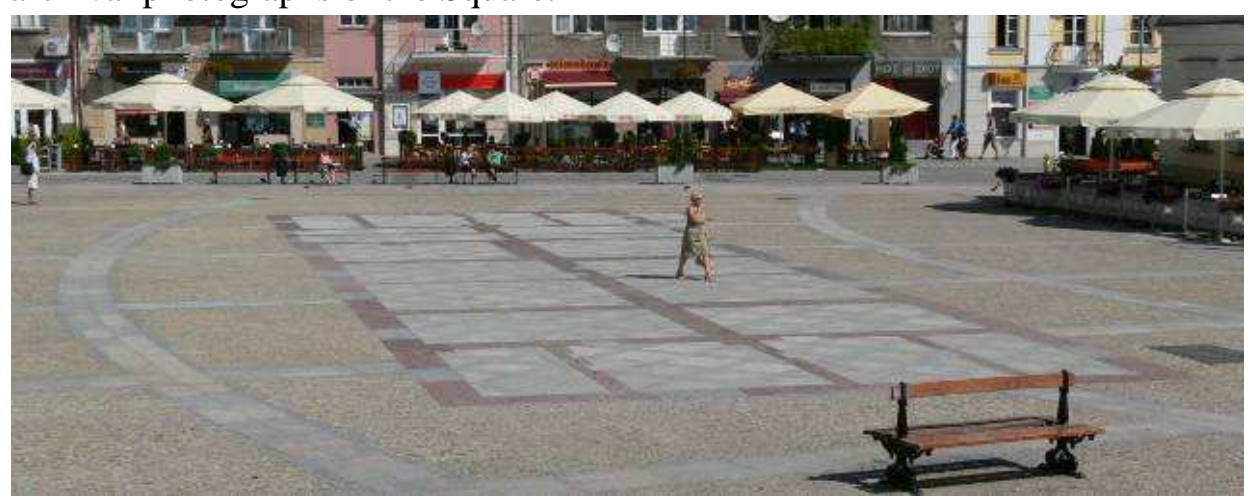

Fig. 6. Drawing of scales building foundations in the floor. Photo by the author

\subsection{Representative function}

The representative floor can be understood as one which residents choose for a place of important celebrations and gatherings.

In the interwar period a square floor was a representative floor - here marches were held, parades of troops, here one organized celebrations of holidays. This tradition was renewed in 1991 when the eastern part of the square near the Sienkiewicz street, a monument of Józef Piłsudski was set. Its neighbourhood became the scene of patriotic celebrations. As a result of the modernization, the monument was moved in front of the building of the former armoury (now the State Archives) and it was set on a stepped platform. At the foot of the monument is the place to enable gatherings.

New floor of Kosciuszko Square is characterized by solutions complexity and is the element that connects the vast space into one inseparable whole. This result was achieved through common surface colouring around the square, consistently designed drawing subordinated to the Square shape and functions of the floor, as well as furnishings. Landscape architecture "grow" from the pavement in planned places and floor design in many places emphasizes their 
location. Most small architecture elements were done in one style (historizing form).

Attention was also given to the lighting of the Square. Besides lanterns, light sources are the lights in the pavement and stairs risers. The facades of some buildings are also floodlit.

Consistency and aesthetics of the new floor have contributed to raising the attractiveness of the area and thus to give it a representative character.

\subsection{Cultural function}

The floor of the Square is today a place of exhibitions and concerts. The choice of site for this type of projects is conditioned by the representative character of the place and a large extent of the floor. In the case of outdoor exhibitions it is crucial for the large number of potential customers-passers.

Performances stage is set mostly in the western part of the Square, on the eastern side of the town hall and part of the Square from the stage to the Sienkiewicz street is reserved for the audience. Sometimes the scene is localized on the western side of the town hall, then the terrain stairs and the area in front of the building is a place of viewers' gatherings.

Exhibitions take place on the eastern side of the Square, in the central part, parallel to the southern frontage or directly in front of the State Archives building being organizer of exhibitions. The western part of the market can be classified as a 'concert', and the eastern as an "exhibition".

\subsection{Recreational function}

The Square is equipped with a large number of various seats [6]. Types of presented here new seats are: cast iron benches with wooden two-way seats, made of stone around the fountain, made of glass and stone in front of the town hall. The terrain stairs can also be used as seats. Benches are sometimes grouped together with other objects of small architecture. Depending on the weather and the preferences one can choose a place which is shady, sunny, with a different view.

Fountain, commonly tied to recreation, is a point on a town map known and characteristic to all, it is also a landmark and a place of meetings.

As a result of modernization Square vanished, some trees were left, and pots of trees were set. Green is complemented by the pots with flowers and bushes and floral baskets hung on lampposts.

Recreational function of the floor is also its use during different types of sporting events - e. g. in the winter an ice rink is built. 


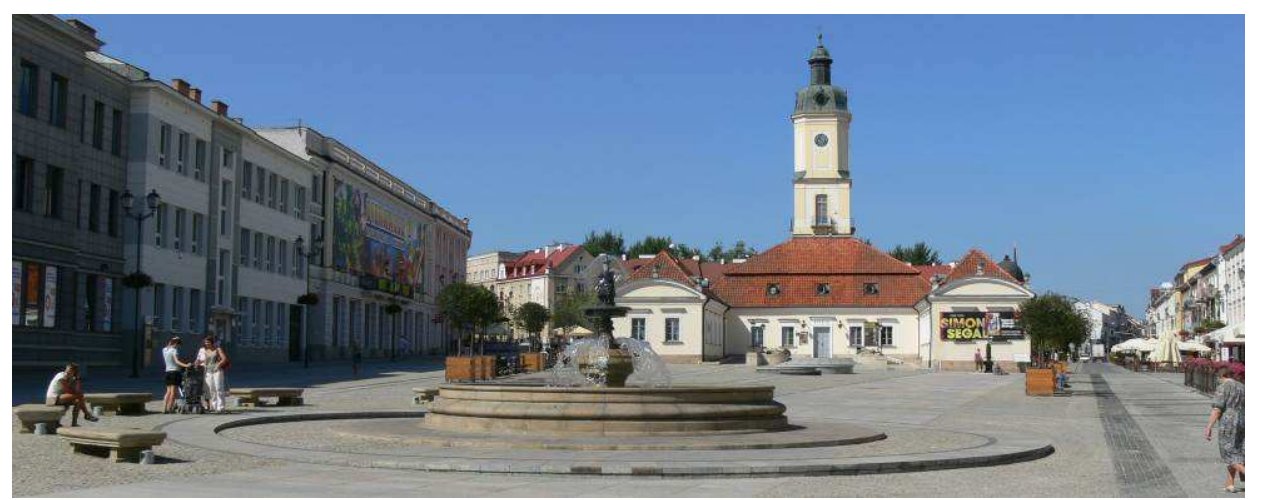

Fig. 7. Kosciuszko Square- a fountain in the background of the town hall. Photo by the author

\section{CONCLUSIONS}

Kosciuszko Square floor has different functions. Most of them there would not have come into being or could not have developed if one had not modernized it and made a decision to exclude the vehicular traffic from part of Square.

The floor of the Square was shaped with care of representative character, and one of the objectives was to make it the media information about the history of the place. The extent of the floor allowed using it as the scene of various types of events. The new surface allows you to emphasize the role played by an important and historic buildings, is the foreground. Its design is original, harmonizing with the architecture, filling vast area; it carries historical content and takes into account the location of landscape architecture.

In the case of the Kosciuszko Square flooring role, as a catalyst for the formation of a cultural area, is superior. Questionable is whether the Kosciuszko Square can now be regarded as a cultural area. Probably yes, although this assessment may be somewhat "exaggerated". For the emergence of a cultural area one needs time, certain traditions, customs and habits of the residents. About the Kosciuszko Square one can say that it is a cultural area as far as it is possible after only a few years of modernisation.

\section{REFERENCES}

1. Gawryluk G.: Wykorzystanie wspótczenych technologii budowlanych w modernizacji $i$ rekonstrukcji wybranych obiektów $i$ przestrzeni historycznych $w$ Białymstoku, Czasopismo Techniczne Politechniki Krakowskiej, 2-A/1/2011 57-64. 
2. Glinka J.: Plan Białegostoku w końcu XVIII stulecia, w: Prace Instytutu Urbanistyki i Architektury, zeszyt 1/14. Studia z historii budowy miast. Warszawa, Budownictwo i Architektura 1955, 221-223.

3. Kietliński M.: Jak się zmieniat Rynek Kościuszki? [online] Archiwum Państwowe w Białymstoku [dostęp grudzień 2014]. Dostępny w Internecie: http://serwer1348234.home.pl/arch/index1.html.

4. Kłopotowska A., Kłopotowski M.: Rynek miejski na antropologicznej mapie śródmieścia Białegostoku, w: Teka Komisji Architektury, Urbanistyki i Studiów Krajobrazowych IVb. Państwowa Akademia Nauk Odział w Lublinie, 2008, 102-116.

5. Tofiluk A.: praca doktorska Podłoga wspótczesnych przestrzeni publicznych jako zagadnienie urbanistyczne na przykładzie wybranych miast polskich. Praca powstała w Katedrze Urbanistyki i Gospodarki Przestrzennej Wydziału Architektury Politechniki Warszawskiej pod opieką prof. zw. dr hab. inż. arch. Andrzeja Gawlikowskiego, 2013.

6. Tofiluk A.: Miejsca i urzqdzenia do siedzenia $w$ przestrzeni publicznej miasta, w: Ergonomia $w$ architekturze $i$ urbanistyce. Kierunki badań $w$ 2014 roku, red. J. Charytonowicz, Wrocław, Wydawnictwo Polskiego Towarzystwa Ergonomicznego PTErg 2014, 39-48.

7. Tofiluk A.: Zagospodarowanie przestrzeni publicznych dziś i jutro teraźniejszość i przyszłość terenów wspólnych $w$ mieście, w: Przyszłość Architektury, red. E. Przesmycka, E. Trocka-Leszczyńska, Wrocław, Wydział Architektury Politechniki Wrocławskiej 2014, 223-238.

8. Wallis A.: Informacja i gwar, Warszawa, PIW 1979.

9. Wejchert K.: Elementy kompozycji urbanistycznej, Warszawa, Arkady 1984.

\section{MODERNIZACJA PODŁOGI PRZESTRZENI PUBLICZNEJ I JEJ WPŁYW NA FUNKCJONOWANIE OBSZARU NA PRZYKŁADZIE RYNKU KOŚCIUSZKI W BIAEYMSTOKU.}

\section{Streszczenie}

Ostatnie 25 lat było w wielu polskich miastach okresem intensywnych modernizacji przestrzeni publicznych, które w dużej części sprowadzały się do wymiany nawierzchni i obiektów małej architektury. W bardzo wielu przypadkach przeobrażenia w obszarze miejskiej podłogi szły w parze z wyłączeniem danej części miasta z ruchu kołowego lub ze znacznym jego ograniczeniem. Powstaje pytanie jakimi kryteriami kierują się projektanci i jakie rozwiązania stosują. Interesujące jest również to na ile nowe 
MODERNIZATION OF PUBLIC SPACE FLOOR AND ITS IMPACT ON AREA - THE 131 EXAMPLE OF THE KOŚCIUSZKO SQUARE IN BIAŁYSTOK

ukształtowanie podłogi przestrzeni publicznej (rozumianej tu jako nawierzchnia w powiązaniu z towarzyszącymi jej obiektami małej architektury) może przyczynić się do wykreowania przestrzeni integrującej i aktywizującej mieszkańców. W artykule podjęto próbę odpowiedzi na te pytania w oparciu o rozwiązania nowej podłogi Rynku Kościuszki w Białymstoku zrealizowanej w latach 2005-2009.

Słowa kluczowe: przestrzeń publiczna, nawierzchnia, podłoga miasta, mała architektura.

Editor received the manuscript: $13.03 .2015 \mathrm{r}$. 
